\title{
Effectiveness of Activated Carbon from Cassava Peel Waste to Reduce TSS (Total Solid Suspended) Levels in Batik Liquid Waste
}

\author{
Niken Tri Widayati ${ }^{1}$, Sulhadi $^{2}$, Teguh Darsono ${ }^{2}$ \\ \{nikenwidayati2401@gmail.com, sulhadipati@mail.unnes.ac.id, teguhfisikaunnes@mail.unnes.ac.id\} \\ SMP Negeri 1 Margoyoso, Jalan Kiai Cebolang 17 Margoyoso Pati Central Java Indonesia ${ }^{1}$, \\ Graduated School of Universitas Negeri Semarang, Jalan Kelud Utara III Semarang Central Java \\ Indonesia $^{2}$
}

\begin{abstract}
The results of the first trials show that the TSS content in Batik liquid waste in Pati is quite high at $540.75 \mathrm{mg} / \mathrm{L}$. The study aims to determine the effect of making adsorbents from cassava peel waste which is influenced by the activation of adsorbents on TSS absorption in batik liquid waste. This research method includes the steps of making activated carbon from cassava peel waste, the process of activation of chemical carbon, and the adsorption test of batik liquid waste. Varied variables are for $\mathrm{HCl}, \mathrm{NaOH}$ and without activators. The results showed a decrease in TSS for activator $\mathrm{HCl} 282.135 \mathrm{mg} / \mathrm{L}, \mathrm{NaOH}$ activator $352.375 \mathrm{mg} / \mathrm{L}$ and without activator $386.245 \mathrm{mg} / \mathrm{L}$. Based on research, the adsorbent from cassava skin is good for reducing TSS in batik liquid waste. Carbon activation with activator $\mathrm{HCl}$ is the most effective in absorbing TSS content in Batik liquid waste.
\end{abstract}

Keywords: activated carbon, TSS, batik liquid waste

\section{Introduction}

One of the biggest centers of cassava production in Central Java Province is produced in Pati Regency. The area of the plant is 15, 200 hectares and the production level is 661.975 tons in 2015 [1]. Large cassava production in Pati Regency is not balanced with optimal utilization. The use of cassava is only for the use of the inside, while the utilization of cassava peel waste is limited to animal feed, the rest is disposed of as waste that cannot be used anymore.

The batik industry is one of the producers of liquid waste containing very high levels of pollutants of organic matter [2]. Based on data from the Pati Regency Central Statistics Agency (BPS) in 2017, 37 Bakaran batik industries are centrally located in Juwana District. Colorant waste in textiles can cause environmental pollution (soil and water) if accumulated in the long term [3]. Most of the liquid waste produced directly discharged into sewers without processing so that it can cause environmental pollution.

The liquid waste of the batik industry is based on the highest physical characteristics containing Total Solid Suspended (TSS) [4]. Excess TSS content will cause turbidity in the water, and then dumped directly into the environment will reduce the light entering the water so 
that it disturbs the sustainability of the water ecosystem. TSS is a solid or suspended particle in water which can be a biotic and abiotic component [5].

Based on the initial laboratory test on May 12, 2019, TSS levels of Bakaran batik wastewater were $540.75 \mathrm{mg} / \mathrm{L}$. The results exceeded the threshold based on the Regulation of the Minister of Environment in 2010 No. 1 concerning the management of water pollution, namely for the TSS content in wastewater of $400 \mathrm{mg} / \mathrm{L}$. So, that the excess TSS content in liquid batik waste can disrupt the sustainability of the water ecosystem

The solution offered to reduce TSS from the Batik Bakaran industry is to process cassava peel waste into carbon. Carbon has excellent adsorption and thermal stability, so the adsorption properties make carbon widely used as a filter medium for various types of pollutants [6].

The purpose of this study was to determine the effect of making adsorbent from the cassava peel waste which is influenced by the activation process of adsorbents on TSS absorption in the batik liquid waste industry.

Adsorbents from carbon materials can utilize cassava peel waste as a medium for batik liquid waste adsorption. Making carbon from cassava peel waste can reduce the solid pollutant of a cassava peel waste, liquid waste to batik adsorbed by carbon so that the waste does not pollute the environment when disposed of into sewers. The results of the study are expected to be useful as the utilization of solid waste of cassava peel waste and overcoming problems in batik liquid waste processing.

\section{Methods}

The method in this study is an experimental quantitative experiment that is the utilization of cassava peel waste as an adsorbent of TSS content in the liquid waste of the batik industry. The study used variations of acid activator $(\mathrm{HCl} 0.1 \mathrm{M})$, base activator $(\mathrm{NaOH} 0.1 \mathrm{M})$, and without activator as a control variable. The determination of TSS content was measured using laboratory tests at the Agricultural Research Agency.

\subsection{Research Tools and Materials}

The tools used in this study are furnaces, ovens, hot plates, digital scales, blenders, $250 \mathrm{ml}$ measuring cups. The materials needed in this study are batik liquid waste, cassava peel waste (adsorbent), aquades, $0.1 \mathrm{M} \mathrm{HCl}$ solution, and $1 \mathrm{M} \mathrm{NaOH}$ solution.

\subsection{Making Carbon from The Cassava Peel Waste}

Cassava peel waste is cleaned and washed to remove clay and other inorganic impurities, then the cassava peel waste used was only the white part and then dried in the sun to dry. The drying process aims to reduce the water content. After drying, cassava peel waste was burned in the furnace for 2 hours with a constant temperature of $400 \mathrm{oC}$. Furthermore, cassava peel waste which has become activated charcoal undergoes a blending process to reduce its size.

\subsection{Chemical Carbon Activation Process}

The refined cassava peel waste is then activated by soaking it using $250 \mathrm{ml}$ activator acid $(\mathrm{HCl}) 0.1 \mathrm{M}$ for 1 hour. After that, the carbon was filtered using filter paper and then rinsed with distilled water to neutral $\mathrm{pH}$. Charcoal that has become activated carbon is then dried using an oven for 3 hours at $110 \mathrm{oC}$, using the same steps the experiment was repeated by replacing activator $(\mathrm{NaOH}) 1 \mathrm{M}$. 


\subsection{Adsorption Test}

The liquid wastewater of Bakaran batik was tested for its adsorption by inserting it into the media, which maintained the composition of activated carbon from cassava peel waste, zeolite, and silica. Next the filtration, wastewater was taken 1 liter for each different type of activator and then the adsorbent results were tested on the TSS content.

\section{Result and Discussion}

The adsorbent in this study used cassava peel waste which were dried, baked and refined as an incineration process and finally blended to reduce the size. Physically activated evaporation in volatile materials and impurities in cassava peel waste, so that empty cavity or pores can be formed which can function as adsorbents [7]. Activated carbon, activated by using activator $\mathrm{HCl} 0.1 \mathrm{M}$ and $\mathrm{NaOH} 1 \mathrm{M}$. Then the adsorbent is washed using distilled water, which aims to remove non-cellulose components attached to the adsorbent so that the $\mathrm{pH}$ content in activated carbon is close to normal. Adsorption of cassava peel waste adsorbent on TSS content of Bakaran Batik liquid waste can show that on table 1.

Table 1. Adsorption of Cassava Peel Waste Adsorbent on TSS Content of Bakaran Batik Liquid Waste

\begin{tabular}{cccc}
\hline Type of Activator & $\mathrm{TSS}_{0}$ & $\mathrm{TSS}_{1}$ & \% Adsorption \\
\hline $\mathrm{HCl}$ & 540.75 & 282.135 & 47.83 \\
$\mathrm{NaOH}$ & 540.75 & 352.375 & 34.84 \\
Without using & 540.75 & 386.245 & 28.57 \\
Activator & & & \\
\hline
\end{tabular}

Information : $\mathrm{TSS}_{0}$ The initial TSS content in Bakaran Batik liquid waste; $\mathrm{TSS}_{1}$ The final $\mathrm{TSS}$ content in Bakaran Batik liquid waste.

Based on table 1 the use of adsorbents can reduce TSS content in batik liquid waste. The results of adsorption on $\mathrm{HCl}$ activators were $47.83 \%, 34.84 \% \mathrm{NaOH}$ and without using activator was $28.57 \%$. the results of the adsorption test for activator $\mathrm{HCl} 0.1 \mathrm{M}$, the absorption efficiency was greater than that of using $\mathrm{NaOH} 1 \mathrm{M}$ activator and without activator which reached $47.83 \%$.

The use of cassava peel waste as pollutant removers in liquid waste Batik can be useful to reduce cassava peel waste in the environment. The results showed that carbon derived from cassava peel waste showed a fairly good adsorbent but had a weakness in its absorbent. Increased carbon absorption is done through the activation process. Activation carried out in this experiment is chemical. This method serves to degrade organic molecules during the carbonization process, limiting tar formation, helping decomposition of organic compounds, dehydrating water trapped in carbon cavities, helping to eliminate the resulting hydrocarbon deposits and protecting carbon [8].The effect of the activator's type on cassava peel waste adsorbent for TSS absorption in the batik liquid waste can be shown in figure 1 . 


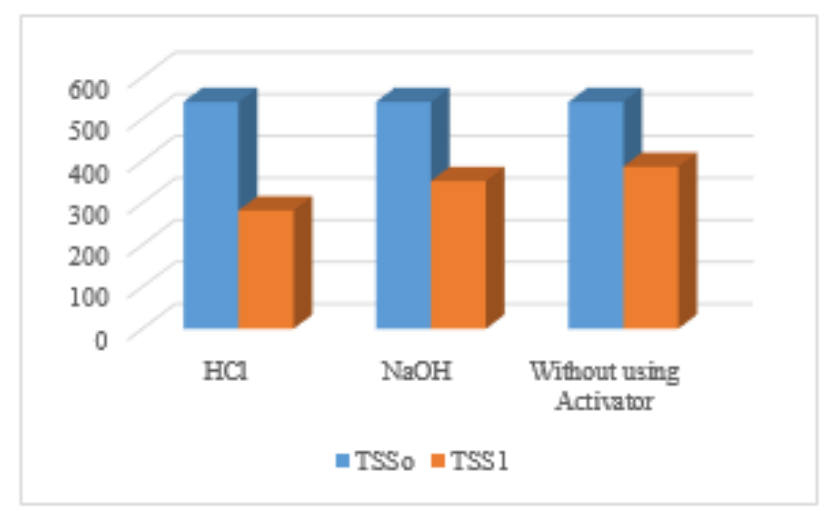

Figure 1.The Effect of Cassava Peel Waste Adsorbent Activator Type on TSS Absorption of Batik Liquid Waste

The results of the research shown in Figure 1 show that the adsorbent activated using 0.1 $\mathrm{M}$ activator $\mathrm{HCl}$ had the highest percentage of TSS absorption when compared to activators using $\mathrm{NaOH} 1 \mathrm{M}$ and adsorbents without activator. The use of activator on the adsorbent obtained a percentage of adsorbent absorption without activator of $28.57 \%$, absorption using activator $\mathrm{NaOH}$ was $34.84 \%$, while the adsorbent using activator $\mathrm{HCl}$ was $47.83 \%$. Adsorbents with the use of activators have greater absorption when compared without using an activator. This is because the carbon activation process from cassava peel waste with $0.1 \mathrm{M} \mathrm{HCl}$ and $1 \mathrm{M}$ $\mathrm{HCl}$ can dissolve tar and inorganic minerals. The loss of the substance from the activated charcoal surface causes the pores of the activated carbon to open to be larger so that it can increase the active charcoal surface area and the ability to absorb the activated carbon [9].

The activation process on carbon can cause the absorption ability to increase when compared to carbon without using activation. This activation process causes the clogging impurities in the carbon pores to disappear so that the amount in the active pores gets bigger. The greater the surface area of activated carbon, the greater the absorption power.

Activation of carbon using acids will produce carbon with greater activity, greater the carbon surface acidity, and good porosity. A chemical activity using $\mathrm{HCl}$ aims to make the surface of carbon acidic, so that the adsorption capacity of carbon becomes larger [10]. Activation using $\mathrm{HCl}$ can dissolve impurities more than activator $\mathrm{NaOH}$, so that carbon, activated with $\mathrm{HCl}$ has more pores formed and the absorption process will be more maximal [11]. After the activation process using $\mathrm{HCl}$ is done, the carbon is washed using distilled water to neutralize the $\mathrm{pH}$ close to normal [12]. This is done to eliminate the excess acid content from $\mathrm{H}^{+}$ions in the immersion process in $\mathrm{HCl}$.

Carbon activation using $\mathrm{NaOH} 1 \mathrm{M}$ aims to form delegations on the adsorbent. Determination function delegates so that dissolved compounds such as lignin can inhibit the adsorption process. Lignin as a barrier to the transfer of ions to the active side of the adsorbent. The $\mathrm{NaOH}$ solution breaks down between cellulose and lignin bonds. The $\mathrm{OH}^{-}$ion from $\mathrm{NaOH}$ breaks the bonds of lignin structure so that lignin will easily dissolve [13]. $\mathrm{NaOH}$ is used to activate and play a role in opening internal micro pore cavities, resulting in an increase in the surface area of the adsorption plane [14].

Based on the results of the experiments, the use of carbon activation with $\mathrm{HCl}$ is the most effective in the absorption of TSS levels in Batik Bakaran liquid waste because it has the highest absorption percentage when compared with the use of $\mathrm{NaOH}$ activator and without activator on 
activated carbon from cassava peel waste. Making carbon from cassava peel waste can reduce the solid pollutant of cassava peel waste, liquid waste of batik adsorbed by carbon so that the waste does not pollute the environment when disposed of into sewers. The results of the experiments are expected to be useful as the utilization of solid waste of cassava peel waste and overcoming problems in batik liquid waste processing.

\section{Conclusion}

Cassava peel waste adsorbents can reduce the TSS content in the Batik wastewater industry which is influenced by the activation process, carbon activation with activator $\mathrm{HCl}$ is the most effective in absorbing TSS waste in Batik liquid waste. The results showed a decrease in the TSS for activator $\mathrm{HCl} 282.135 \mathrm{mg}$ / L with an adsorption percentage of $47.83 \%$, activator $\mathrm{NaOH}$ $352.375 \mathrm{mg} / \mathrm{L}$ with a percentage of adsorption $34.84 \%$ and then without activator 386.245 $\mathrm{mg} / \mathrm{L}$ for the percentage of adsorption $28.57 \%$. 


\section{References}

[1] Badan Pusat Statistik. Luas Panen, Produksi, dan Produktivitas Ubi Kayu dan Ubi Jalar Menurut Kabupaten/Kota di Provinsi Jawa Tengah. Retrieved from https://jateng.bps.go.id/statictable/2016/08/22/1314/luas-panen-produksi-dan-produktivitas-ubi-kayudan-ubi-jalar-menurut-kabupaten-kota-di-provinsi-jawa-tengah-2015.htm (2018)

[2] Suprihatin, H.: Kandungan Organik Limbah Cair Industri Batik Jetis Sidoarjo dan Alternatif Pengolahannya. Jurnal Pusat Penelitian Lingkungan Hidup, Vol. 6, pp. 1-13 (2014)

[3] Gonawala, K.H \& Mehta, M.J.: Removal of Color from Different Dye Wastewater by Using Ferric Oxide as an Adsorbent. Journal of Engineering Research and Application, Vol. 4, pp. 102-109 (2014) [4] Dewi, R.S., Kasiamdari, R.S., Martani, E. \& Purwestri, artani, E. \& Purwestri, Y.A.: Bioremediation of Indigosol Blue 04B Batik Effluent by Indigenous Fungal Isolates, Aspergillus spp. Journal OmniAkuatika., Vol. 14, pp. 11-20 (2018)

[5] Ainy, K., Siswanto, A.D. \& Nugraha,W.A.: Sebaran Total Suspended Solid (TSS) di Perairan Sepanjang Jembatan Suramadu Kabupaten Bangkalan. Jurnal Kelautan, Vol. 4, pp. 158-162 (2011)

[6] Kurniawan, J., Wati, A.L., Rahmawati, Ita., Sulhadi., Priyanto, A. \& Aji, M.P.: Pemanfaatan Limbah Ubi Kayu dari Sisa Pengolahan Tepung Tapioka di Kecamatan Margoyoso Kabupaten Pati menjadi Bahan Adsorben untuk Penjernih Air. Prosiding Seminar Nasional Fisika (E-Journal),Vol. 6, pp. 43-48 (2017)

[7] Herawati, D., Santoso, S.D. \& Amalina, I.: Kondisi Optimum Adsorpsi-Fluidisasi Zat Warna Limbah Tekstil Menggunakan Adsorben Jantung Pisang. Jurnal SainHealth, Vol. 2, pp. 1-7(2018)

[8] Alfiany, H.,Bahri, S. \& Nurakhiwati: Kajian Penggunaan Arang Aktif Tongkol Jagung sebagai Adsorben Logam Pb dengan Beberapa Aktivator Asam. Jurnal Natural Science, Vol. 2, pp. 75-86 (2013)

[9] Nurulita, U. \& Mifbakhuddin: Adsorption of Carbon Monoxide (CO) in A Room By Coconut Shell And Durian Skin Activated Carbons. Jurnal Kesehatan Masyarakat Unnes, Vol.12, pp. 60-67 (2016)

[10] Bijang, C.M., Nurdin, M., Tehubijulluw, H.,Fransina,E.G.,Uyara, T. \& Suarti.: Application of Ouw Natural Clay Activated Acid and Base as Adsorbent of Rhodamine B Dye. Journal of Physics. Vol. 1242,pp. 1-4 (2018)

[11] Myglvets, M., Poddubnaya, O.I., Sevastyanova, O., Lindstrom, M.E., Gawdzik,B., Sobiesiak, M., Tsyba, M.M., Sapsay, V.I., Klymchuk, D.O. \& Puziy, A.M.: Preparation of Carbon Adsorbents from Lignosulfonate by Phosporic Acid Activation for the Adsorption of Metal Ions. Carbon, Vol.8, pp. 771-783 (2014)

[12]Boyd, C.E., Tucker, C.S. \& Viriyatum, R.: Interpretation of pH, Acidity, and Alkalinity in Aquaculture and Fisheries. North American Journal of Aquaculture,Vol. 71,pp. 403408(2011)

[13] Mandasari, I. \& Purnomo A.: Penurunan Ion Besi (Fe) dan Mangan (Mn) dalam Air dengan Serbuk Gergaji Kayu Kamper. Jurnal Teknis ITS, Vol. 6, pp. 11-16(2016)

[14] Ahmad, A.F. \& El-Chagaby, G.A.: Adsorption of Citric Acid from Aqueous Solution on to Activated P. Lentiscus Leaves. Internasional Researches Journal of Environmental Sciences, Vol. 1, pp. 7-13 (2012) 